\title{
Temperament characteristics of children with persistent and recovered stuttering: A longitudinal study*
}

\author{
HeeCheong Chon** \\ Department of Speech-Language Pathology, Chosun University, Gwangju, Korea
}

\begin{abstract}
The purpose of this study was to investigate the temperament characteristics associated with stuttering subtypes (persistent and recovered) over time and the relationship between those characteristics and stuttering severity. This four-year longitudinal study covered 41 preschool children who stutter (CWS) and 30 preschool children who do not stutter (the CWNS group). At the final visit, 27 CWS were classified as the Recovered group and 14 CWS were classified as the Persistent group. Using the Children's Behavior Questionnaire-Short Form, each participant's temperament characteristics were measured twice: at one year and two years after the initial visit. The three subscale scores (Extraversion, Negative Affectivity, and Effortful Control) and the 15 component scores were analyzed, and they were used for between-group and between-visit comparisons. The Persistent group showed a significantly higher Negative Affectivity subscale score at every visit than the Recovered and CWNS groups. Within this subscale, significant group differences were found in the 'Fear' and 'Anger/Frustration' components, demonstrating that the Persistent group scored higher than the Recovered and CWNS groups. There was no significant correlation between the subscale and component scores and the stuttering severity scores within the Persistent group at any visit. These results support the proposition that these two stuttering subtypes have different temperament characteristics; they also imply that temperament might be influenced by stuttering experience over time.
\end{abstract}

Keywords: childhood stuttering, longitudinal study, persistence, recovery, subtype, temperament

\section{1. 서론}

기질(temperament)은 개인이 지니고 있는 선천적인 경향성으 로(Buss \& Plomin, 1984), 개인차를 보이는 정서적 반응성과 반
응성의 자기-조절(self-regulation; Rothbart \& Derryberry, 1981)을 의미한다. 기질은 유전적인 측면을 가지고 있고 비교적 지속적 인 모습을 보이지만 시간이 지나면서 개인이 겪게 되는 경험이 나 처한 환경, 성숙 등의 영향을 받는다(Bates et al., 1979; Buss

\footnotetext{
* The research was conducted through the Illinois International Stuttering Research Program at the University of Illinois at Urbana-Champaign. This work was supported by grant \# R01-DC05210 from the National Institutes of Health, National Institute on Deafness and Other Communication Disorders (First PI: Ehud Yairi; second PI: Nicoline G. Ambrose).

** hchon@chosun.ac.kr, Corresponding author Received 16 November 2021; Revised 9 December 2021; Accepted 9 December 2021

(c) Copyright 2021 Korean Society of Speech Sciences. This is an Open-Access article distributed under the terms of the Creative Commons Attribution NonCommercial License (http://creativecommons.org/licenses/by-nc/4.0) which permits unrestricted non-commercial use, distribution, and reproduction in any medium, provided the original work is properly cited.
} 
\& Plomin, 1984; Putnam \& Rothbart, 2006; Rothbart \& Derryberry, 1981). 개인의 기질 특성을 살피는 방법은 다양하지만 어린 아 동의 전반적인 기질 특성을 파악하기 위하여 선행연구들은 주 로 질문지나 검사지를 사용한 주 양육자의 보고 방법을 사용하 여왔다(Ambrose et al., 2015; Anderson et al., 2003; Howell et al., 2004; Putnam \& Rothbart, 2006; Reilly et al., 2009; Reilly et al., 2013). 연구자가 실험 혹은 과제 상황에서 아동을 관찰하는 경 우 통제된 상황 안에서 아동의 특정 기질 특성을 직접 살필 수 있지만(Eggers et al., 2013; Ntourou et al., 2013) 아동의 기질 특 성을 포괄적으로 살펴보기는 어렵기 때문이다.

발달성 말더듬(이하 말더듬)은 아직까지 정확한 원인이 밝혀 지지 않은 말장애이다. 또한 다른 의사소통장애와는 달리 말더 듬는 사람 중 약 $79 \%$ 는 말더듬에서 회복되며 약 $21 \%$ 는 말더듬 이 지속되는 하위유형(subtype)을 가지고 있다(Yairi \& Ambrose, 2005). 최근 연구들은 유전, 뇌의 구조 및 기능, 기질, 말운동통 제, 말-언어발달 등 말더듬과 관련된 여러 요인들을 보고하고 있으며(Ambrose et al., 2015; Chang et al., 2015; Conture et al., 2006; Kang et al., 2010; Walsh et al., 2015; Watkins, 2005), 다양한 요인들의 상호작용으로 인해 말더듬이 시작되고 지속 혹은 회 복되는 것으로 설명하고 있다(Smith \& Weber, 2017). 이 중 기질 은 말더듬 관련 이론에서 지속적으로 다루어지고 있는 요인이 다. Smith \& Weber(2017)는 역동적 다중요인 경로 이론 (multifactorial dynamic pathways theory)을 통하여 말더듬의 시작 과 진전에 영향을 미칠 수 있는 요인 중 하나가 정서적인 요인 이라고 하였다. 수정된 구성모델(revised component model)을 주 장한 Riley \& Riley(2000)는 학령전 및 학령기 말더듬 아동 (children who stutter, CWS)에게서 관찰된 말더듬 관련 요인 중 하나가 기질이었다고 하였다. CWS는 높은 자기-기대(selfexpectation)와 과민감성을 보였으며, 특히 자기-기대의 경우 전 체 CWS 중 $66 \%$ 가 자기-기대가 비정상적으로 높았다고 하였다 (Riley \& Riley, 2000). 또한 Conture et al.(2006)은 의사소통-정서 모델(communication-emotional model)을 통하여 CWS가 자신의 비유창성에 대해 보이는 정서적 반응과 같은 기질 특성이 말더 듬의 지속 혹은 악화에 영향을 끼칠 수 있는 요인이 될 수 있다 고 하였다.

기질과 말더듬 간의 관련성을 살핀 연구들은 기질이 말더듬 의 시작 혹은 지속과 관련된 요인인지 확인하기 위하여 학령전 CWS 집단과 말을 더듬지 않는 아동(children who do not stutter, $\mathrm{CWNS}$ ) 집단 간 비교를 실시하였다. 하지만 선행 연구들은 두 집단 간 기질에 차이가 없었다는 결과와(Arnold et al., 2011;
Reilly et al., 2009; Reilly et al., 2013; van der Merwe et al., 2011) 두 집단 간 기질에 차이가 있었다는 결과가(Anderson et al., 2003; Eggers et al., 2010; Embrechts et al., 2000; Felsenfeld et al., 2010; Howell et al., 2004; Lee et al., 2020; Ntourou et al., 2013) 혼 재하고 있다. 또한, 두 집단 간 기질에 차이가 있었다 하더라도 차이를 보이는 기질 특성이 연구마다 다소 다른 모습을 보이고 있다. 예를 들어, 집단 간 차이를 보고한 연구 중 일부 연구는 $\mathrm{CWS}$ 가 CWNS보다 활동수준이 높았고, 더 적극적이었고 충동 적이었으며, 자극에 과민하게 반응하였고, 적응성이 낮았고, 분 노/좌절 경향이 높았고, 더 부정적이었으며, 자극의 통제력과 주의집중력이 낮았다고 하였다(Anderson et al., 2003; Eggers et al., 2010; Embrechts et al., 2000; Felsenfeld et al., 2010; Howell et al., 2004; Ntourou et al., 2013). 반면 다른 연구는 CWS가 CWNS 에 비해 인내력이 더 높았으며, 적응성이 높았고, 덜 부정적이 었다고 보고하기도 하였다(Lee et al., 2020; Lewis \& Golberg, 1997). 동일한 검사도구를 사용하여 CWS와 CWNS를 비교한 연 구의 경우에도 기질 특성 결과가 다른 모습을 보이기도 하였다 (Anderson et al., 2003; Eggers et al., 2010; Embrechts et al., 2000; Howell et al., 2004). 이러한 비일관적인 연구 결과는 연구에 참 여한 CWS 집단과 CWNS 집단의 연령이나 기질 측정방식의 다 양성 등 실험설계 상의 차이로 인한 것도 있겠지만 말더듬이 하 위유형을 가지고 있는 이질적인(heterogeneous) 장애(Yairi \& Ambrose, 2005)라는 것을 뒷받침하는 결과로 해석할 수 있다. 따라서 기질과 말더듬의 관련성을 명확하게 밝히기 위해서는 CWS 집단을 말더듬 지속 여부에 따른 하위유형으로 나누고 하 위유형에 따른 기질 특성이 어떠한지 비교할 필요가 있으며 (Ambrose et al., 2015), 종단연구를 통하여 말더듬과 관련된 지 속적인 경험이 시간이 지나면서 기질에 영향을 미치는지 확인 해야 한다.

종단연구를 통하여 $\mathrm{CWS}$ 의 기질 특성을 살폈던 연구는 제한 적으로 이루어졌다(Ambrose et al., 2015; Kefalianos et al., 2017; Reilly et al., 2009, Reilly et al., 2013). Reilly와 동료들(2009, 2013)은 말더듬 시작 시기의 특성을 파악하기 위하여 8개월 아 동들을 대상으로 종단연구를 실시하였다. 종단연구 기간에 말 더듬이 시작된 아동 집단과 말을 더듬지 않은 아동 집단으로 분 류하고, 아동이 2 세가 되었을 때와 4세가 되었을 때 측정한 기 질 특성을 집단 간 비교한 결과 두 집단은 기질 특성, 즉, 접근성 (approach or withdrawal) 점수를 통해 파악한 수줍음/내향성 수 준에 차이가 없는 것으로 나타났다(Reilly et al., 2009; Reilly et al., 2013). 또한 수줍음/내향성 수준은 말더듬의 시작을 예측할 
수 있는 요인이 아니었다고 보고하였다(Reilly et al., 2013). 이후 말더듬 아동들이 7세가 되었을 때 말더듬이 지속된 아동 집단 과 말더듬에서 회복된 아동 집단으로 분류하고 집단 간 비교를 실시한 결과, 두 집단은 수줍음/내향성 수준에 차이가 없었으 며, 순한 기질/까다로운 기질 점수에도 차이가 없었다고 하였다 (Kefalianos et al., 2017). 하지만 이 종단연구는 아동의 전반적인 기질 특성을 살피지 않았다는 제한점이 있다. Ambrose et al. (2015)은 말더듬 시작 이후 지속기간(post-onset of stuttering)이 12 개월 이내인 $\mathrm{CWS}$ 를 대상으로 종단연구를 실시하여 최종적 으로 $\mathrm{CWS}$ 를 말더듬이 지속된 아동과 말더듬에서 회복된 아동 의 두 하위유형 집단으로 분류하고, 말더듬 하위유형 집단과 $\mathrm{CWNS}$ 집단의 기질이 어떠한 특성을 보이는지 살펴보았다. 아 동이 종단연구에 참여하였던 첫 평가 시에 수집한 기질 자료를 분석하여 말더듬의 시작과 인접한 시점의 기질 특성을 비교한 결과, 말더듬이 지속된 아동 집단은 말더듬이 회복된 아동 집단 과 CWNS 집단보다 부정적 정서가 높은 것으로 나타났다. 또한 말더듬이 지속된 아동 집단은 부정적 정서에 포함되는 기질의 하위영역 중 공포 수준이 다른 아동 집단보다 유의하게 높았으 며 반응회복율/진정성[“극도의 고통, 흥분, 혹은 일반적인 각성 으로부터 회복되는 정도(Putnam et al., 2008:389)”] 수준이 유의 하게 낮았다고 하였다. 말더듬에서 회복된 아동 집단의 기질 특 성은 CWNS 집단과 유의한 차이를 보이지 않았다. 이 결과는 말 더듬 하위유형에 따라 장애의 시작과 인접한 시기에 기질 차이 가 존재하고 있었음을 확인하였다는 것에 의의가 있다. 하지만 첫 평가 시에 발견된 기질의 차이가 실제로 말더듬의 지속 혹은 회복과 관련이 있는지, 시간이 지나면서 말더듬과 말더듬으로 인한 반복적인 경험들이 CWS의 기질에 영향을 미치는지 살피 기 위해서는 종단적으로 $\mathrm{CWS}$ 의 전반적인 기질 특성을 파악할 필요가 있다.

따라서 본 종단연구는 Ambrose et al.(2015)의 후속 연구로서 말더듬의 시작과 인접한 시점이었던 첫 평가 이후 1 년이 지난 시점과 2 년이 지난 시점에서 $\mathrm{CWS}$ 와 $\mathrm{CWNS}$ 의 기질 특성을 비 교하고자 하였다. 특히 CWS의 경우 Ambrose et al.(2015)과 동일 하게 말더듬 하위유형인 말더듬이 지속된 아동과 말더듬에서 회복된 아동으로 집단을 분류하고 비교하여 말더듬 하위유형 에 따른 기질 특성을 보다 명확히 살피고 기질이 말더듬의 지속
혹은 회복과 관련있는지 파악하고자 하였다. 또한 외현적인 말 더듬 중증도와 기질 특성 간 관련성을 살펴보고자 하였다. 연구 문제는 다음과 같다: (1) 말더듬 유무(CWS와 CWNS)와 평가 시 점에 따라 기질 특성에 차이를 보이는가? (2) 말더듬 하위유형 (말더듬이 지속된 아동, 말더듬에서 회복된 아동, $\mathrm{CWNS}$ )과 평 가 시점에 따라 기질 특성에 차이를 보이는가? (3) 말더듬이 지 속된 아동의 외현적인 말더듬 중증도는 기질과 관련이 있는가?

\section{2. 연구방법}

\section{1. 연구 참여자}

\subsection{1. 참여자 선정기준 및 선정과정}

본 연구의 참여자는 Ambrose et al.(2015)의 기질 특성 비교에 참여하였던 총 91 명의 아동 중 아동의 주 양육자인 어머니가 2 년간 총 3 번에 걸친 기질 평가(첫 평가, 1 년 후 평가, 2 년 후 평 가)에 모두 참여하였던 71 명의 아동이었다. 아동과 아동의 주 양육자는 영어를 모국어로 사용하였다. 이 중 $\mathrm{CWS}$ 는 41 명으로, 말더듬이 지속된 아동이 14 명이었으며(말더듬 지속아동 집단: 남아 10 명, 여아 4 명), 말더듬에서 회복된 아동이 27 명이었다(말 더듬 회복아동 집단: 남아 19명, 여아 8명). 첫 평가 시(이하 Visit 1) 모든 CWS는 (1) 아동의 주 양육자가 아동의 말더듬 문제를 보고하였고, 부모 중증도 척도(Parent Severity Scale, Yairi \& Ambrose, 2005)를 사용하여 아동의 말더듬 중증도가 경계선급 이상이라고 하였으며, (2) 부모 보고에 의한 말더듬 시작 이후 지속기간이 12 개월 이내였고, (3) 자발화 분석 결과 100 음절당 3 회 이상의 진성비유창성이 관찰되었으며, (4) 언어재활사가 일 리노이 말더듬 중증도 척도(Illinois Clinician Stuttering Severity Scale, Yairi \& Ambrose, 2005)를 사용하여 말더듬 평가를 실시 한 결과 발달성말더듬으로 진단하였고, (5) 시각, 청각, 혹은 신 경학적 문제를 동반하지 않은 아동이었다.

그림 1 에 제시된 내용과 같이 CWS는 종단연구에 6개월-1년 단위로 4년간 지속적으로 참여하였으며, 마지막 평가(Visit 7)에 서 말더듬이 지속되었는지 혹은 말더듬에서 회복되었는지 최 종 진단을 받았다. 말더듬의 지속과 회복 진단 기준은 Ambrose et al.(2015:15)과 동일하였다. 즉, 말더듬이 지속된 아동은 (1) 아 동의 주 양육자 혹은 아동 본인이 말더듬 문제가 있다고 보고하

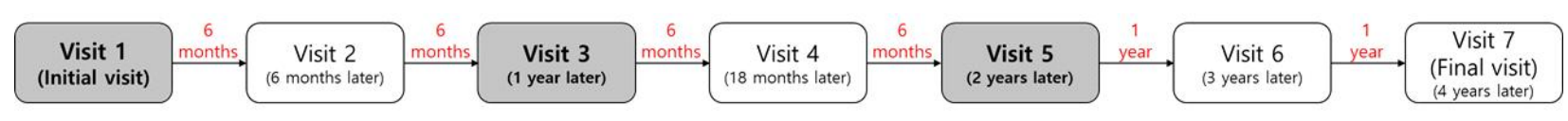

그림 1. 종단연구 절차

Figure 1. Procedures of the longitudinal study 
였거나 (2) 주 양육자가 부모 중증도 척도에서 아동의 말더듬 중 증도가 1 점 이상이라고 하였거나 (3) 자발화 분석결과 100 음절 당 3회 이상의 진성비유창성이 관찰되었거나 (4) 언어재활사가 일리노이 말더듬 중증도 척도를 사용하여 평가한 결과 1 점 이 상의 점수가 나와 말더듬으로 진단한 경우 중 하나 이상의 기준 을 충족한 경우였다. 말더듬에서 회복된 아동은 (1) 아동의 주 양육자가 아동이 말더듬 문제가 없다고 보고하였으며, (2) 주 양 육자가 부모 중증도 척도에서 아동의 말더듬 중증도가 1점 미 만이라고 하였고, (3) 자발화 분석 결과 100 음절당 3 회 미만의 진성비유창성이 관찰되었으며, (4) 언어재활사가 일리노이 말 더듬 중증도 척도를 사용하여 평가한 결과 1 점 미만의 점수가 나와 말더듬이 없다고 진단하였고, (5) 말더듬이 관찰되지 않은 기간이 최소 12 개월 이상이면서 연구 참여를 종료할 때까지 말 더듬이 나타나지 않은 기준을 모두 충족한 경우였다.

CWNS는 30 명(남아 15 명, 여아 15 명)으로 (1) 주 양육자가 아 동이 말더듬 문제가 없음을 보고하였으며, 부모 중증도 척도에 서 1점 미만이라고 하였고, (2) 자발화 분석 결과 100 음절당 3 회 미만의 진성비유창성이 관찰되었으며, (3) 언어재활사가 일리 노이 말더듬 중증도 척도를 사용하여 말더듬 평가를 실시한 결 과 말더듬이 아니라고 진단하였고, (4) 시각, 청각, 혹은 신경학 적 문제를 동반하지 않은 아동이었다. CWNS도 4년에 걸친 종 단연구에 동일하게 참여하였다.

\subsection{2. 참여자 선정 도구}

미국 언어재활사 자격증(CCC-SLP)을 소지하고 박사과정에 서 말더듬을 전공하였으며, 말더듬 평가 및 중재 경험이 풍부한 언어재활사(연구원)는 일리노이 말더듬 중증도 척도를 사용하
여 각 평가 시점마다 아동의 외현적인 말더듬을 평가하였다. 평 가 결과는 최종적으로 0-7점 범위의 점수로 계산되며, 점수를 기준으로 하여 말더듬을 진단하고 중증도를 판정하였다. 중증 도 판정은 0 점은 정상적으로 유창함을 의미하며, 1 점은 경계선 급 말더듬, 2 점은 약한 중증도의 말더듬, 7 점은 매우 심한 중증 도의 말더듬을 의미한다(Yairi \& Ambrose, 2005).

부모 중증도 척도는 0-7점 리커트 척도 한 개 문항으로 이루 어져 있으며, 주 양육자가 종단연구를 위해 방문한 평가 시점을 기준으로 자녀의 전반적인 말더듬 중증도를 생각하여 작성하 게 하였다. 언어재활사의 중증도 판정 기준과 동일하게 0 점은 정상적으로 유창함을 의미하며, 1 점은 경계선급 말더듬, 2 점은 약한 중증도의 말더듬, 7 점은 매우 심한 중증도의 말더듬을 의 미한다(Yairi \& Ambrose, 2005).

표 1 은 연구에 참여한 아동 집단의 정보이다. $\mathrm{CWS}$ 의 경우, 말더듬 지속아동 집단과 말더듬 회복아동 집단으로 구별하여 제시하였으며, 각 평가 시점의 생활연령과 말더듬 중증도 점수 기술통계 값을 제시하였다. Visit 1 의 경우 말더듬 시작 이후 지 속기간의 기술통계 값을 함께 제시하였다. 말더듬 지속아동 집 단과 말더듬 회복아동 집단 간 말더듬 중증도 점수 비교를 위하 여 독립표본 $t$-검정(일리노이 말더듬 중증도 척도로 평가한 언 어재활사의 외현적 말더듬 중증도)과 맨휘트니 검정(부모 중증 도 척도를 사용한 주 양육자의 말더듬 중증도)을 각각 실시하였 다. Visit 1 에서 언어재활사의 말더듬 중증도 점수 $[t(39)=.831$, $p>.05]$ 와 주 양육자의 말더듬 중증도 점수 $[Z=-.904, p>.05]$ 는 집단 간 유의한 차이가 없었다. 그러나 Visit 1 이후 1 년이 지난 시점(이하 Visit 3)에서 언어재활사가 평가한 말더듬 중증도 점 수는 말더듬 회복아동 집단이 유의하게 낮은 것으로 나타났으

표 1. 연구 참여자 정보

Table 1. Participants' characteristics

\begin{tabular}{|c|c|c|c|c|c|}
\hline & & & \multicolumn{2}{|c|}{ CWS } & \multirow[b]{2}{*}{$\begin{array}{l}\text { CWNS } \\
(\mathrm{N}=30)\end{array}$} \\
\hline & & & $\begin{array}{c}\text { Persistent } \\
(\mathrm{N}=14)\end{array}$ & $\begin{array}{c}\text { Recovered } \\
(\mathrm{N}=27)\end{array}$ & \\
\hline \multirow{4}{*}{$\begin{array}{c}\text { Visit } 1 \\
\text { (Initial visit) }\end{array}$} & \multicolumn{2}{|c|}{ Post-onset of stuttering (months) } & $5.93(4.21)$ & $3.56(2.69)$ & - \\
\hline & \multicolumn{2}{|c|}{ Age (months) } & $42.29(11.25)$ & $38.15(7.42)$ & $43.37(11.61)$ \\
\hline & \multirow{2}{*}{$\begin{array}{c}\text { Stuttering } \\
\text { severity score }\end{array}$} & Clinician & $2.70(1.70)$ & $2.33(1.17)$ & - \\
\hline & & Parent & $3.71(1.37), 3.25(2.00)^{1)}$ & $3.37(1.05), 3.00(1.00)^{1)}$ & - \\
\hline \multirow{3}{*}{$\begin{array}{c}\text { Visit } 3 \\
\text { (1 year after } \\
\text { the initial visit) }\end{array}$} & \multicolumn{2}{|c|}{ Age (months) } & $54.57(11.34)$ & $50.67(7.50)$ & $55.67(11.76)$ \\
\hline & \multirow{2}{*}{$\begin{array}{c}\text { Stuttering } \\
\text { severity score }\end{array}$} & Clinician & $1.95(1.10)$ & $1.03(0.99)$ & - \\
\hline & & Parent & $3.14(1.42), 3.00(2.00)^{1)}$ & $1.12(0.77), 1.00(1.00)^{1)}$ & - \\
\hline \multirow{3}{*}{$\begin{array}{c}\text { Visit } 5 \\
\text { (2 years after } \\
\text { the initial visit) }\end{array}$} & \multicolumn{2}{|c|}{ Age (months) } & $66.79(10.93)$ & $62.41(7.20)$ & $67.60(11.63)$ \\
\hline & \multirow{2}{*}{$\begin{array}{c}\text { Stuttering } \\
\text { severity score }\end{array}$} & Clinician & $1.63(0.89)$ & $0.41(0.62)$ & - \\
\hline & & Parent & $2.57(1.09), 2.50(1.00)^{1)}$ & $0.80(0.85), 0.50(1.50)^{1)}$ & - \\
\hline
\end{tabular}

Values are presented as mean (SD).

1) Mean (SD), median (interquartile range).

CWS, children who stutter; CWNS, children who do not stutter; Persistent, children whose stuttering was persisted; Recovered, children whose stuttering was recovered; Clinician, Illinois Clinician Stuttering Severity Scale score; Parent, Parent Severity Scale score. 
며 $[t(39)=2.721, p<.05]$, 부모가 보고한 말더듬 중증도 점수 역시 말더듬 회복아동 집단이 유의하게 낮은 것으로 나타났다 $[Z=-$ 4.216, $p<.001]$. Visit 1 이후 2년이 지난 시점(이하 Visit 5)에서도 Visit 3의 결과와 동일한 결과가 나타났다(언어재활사의 말더듬 중증도 점수: $t(39)=5.167, p<.001$; 주 양육자의 말더듬 중증도 점 수: $Z=-4.242, p<.001)$. 일요인 분산분석 결과, 세 아동 집단의 생활연령은 각각의 평가 시점(Visit 1, Visit 3, Visit 5)에서 유의 한 차이가 없는 것으로 나타났다(각각 $p>.05)$.

2.2. 검사도구: 유아기질척도-간편형

아동의 기질 특성을 살펴보기 위하여 유아기질척도-간편형

(Children's Behavior Questionnaire-Short Form Version I, CBQ$\mathrm{SF}$, Putnam \& Rothbart, 2006)을 사용하였다. CBQ-SF는 195개 문항으로 이루어져 있는 기존의 $\mathrm{CBQ}($ Rothbart et al., 2001) 문항 수를 94 개로 축소시켜 검사의 편의성을 높인 검사도구이다. $\mathrm{CBQ}$ 와 $\mathrm{CBQ}-\mathrm{SF}$ 는 3-7세 아동을 대상으로 측정의 타당도와 신 뢰도가 검증되었으며(Putnam \& Rothbart, 2006; Rothbart et al., 2001), 한국어, 중국어, 일본어, 스페인어, 네덜란드어 등 여러언 어로 번역되어 사용되어 왔다(Ahadi et al., 1993; de la Osa et al., 2014; Kusanagi, 1993; Lee, 2004; Lim \& Bae, 2015; Sleddens et al., 2011). 또한 학령전 혹은 학령기 저학년 $\mathrm{CWS}$ 의 기질 특성을 살피기 위한 목적으로 많은 선행연구에서 사용한 검사도구이 다(Cha, 2015; Choi et al., 2016; Eggers et al., 2009, 2010; Jones et al., 2017).

$\mathrm{CBQ}-\mathrm{SF}$ 는 3 개의 상위요인과 15 개의 하위영역으로 이루어져 있으며, 각 문항은 15 개의 하위영역 중 하나에 포함되어 있다. $\mathrm{CBQ}-\mathrm{SF}$ 의 상위요인은 외향성(extraversion), 부정적 정서 (negative affectivity), 그리고 의도적 통제(effortful control)이다. 외향성에 속하는 하위영역은 5개로, ‘접근성/긍정적 기대', ‘강 한 자극 선호성’, ‘활동수준’, ‘충동성’, ‘수줍음’이고, 부정적 정 서에 속하는 하위영역은 ‘불안’, ‘공포', ‘분노/좌절', ‘슬픔’, ‘반 응회복율/진정성, 5 개이며, 의도적 통제 역시 5 개의 하위영역, 즉, ‘자극의 통제', ‘주의집중력’, ‘낮은 자극 선호성', ‘자극 민감 성', '미소/웃음'을 포함하고 있다(Putnam \& Rothbart, 2006; Putnam et al., 2008). 본 연구는 CBQ-SF의 상위요인과 하위영역 모두를 종속변수로 사용하였다.

\section{3. 자료 수집 및 분석}

본 종단연구는 기관생명윤리위원회의 승인 하에 이루어졌다 (IRB Protocol Number: 02011). 연구 참여자들은 종단연구에 6개 월-1년 단위로 참여하여 4년간 말더듬과 관련된 평가를 받았다.
이중 Visit 1, Visit 3, Visit 5에서 아동의 기질 특성을 살피기 위 한 $\mathrm{CBQ}-\mathrm{SF}$ 검사를 실시하였다. 각 평가 시점마다 아동의 어머 니는 평가가 이루어지는 실험실 내 조용한 공간에서 아동이 말 더듬 관련 평가를 받는 동안 부모 중증도 척도에 아동의 말더듬 중증도를 기록하고 $\mathrm{CBQ}-\mathrm{SF}$ 를 작성하였다. $\mathrm{CBQ}-\mathrm{SF}$ 의 문항은 1 -7점 리커트 척도로 답하게 되어 있으며, 1점은 '매우 그렇지 않 다(extremely untrue)'를 의미하고 7점은 '매우 그렇다(extremely true)'를 의미한다. 아동의 어머니는 CBQ-SF의 각 문항을 읽고 검 사 시점을 기준으로 6 개월 이내에 아동에게 해당하는 가장 적절 한 점수를 선택하여 검사지에 표시하였고, 만일 아동에게 해당되 지 않는 문항인 경우 ‘해당 없음(not applicable)'에 표시하였다.

각 하위영역의 점수는 하위영역에 포함되는 문항들 중 아동 의 어머니가 응답한 문항의 점수를 모두 더한 후 응답한 문항의 수로 나누어 얻은 평균 점수였다. 만일 아동의 어머니가 문항에 응답하지 않았거나 ‘해당 없음'에 표시한 경우 그 문항은 평균 점수를 계산할 때 제외하였다(Putnam \& Rothbart, 2006; Rothbart et al., 2001). CBQ-SF의 전체 문항 중 31 개 문항은 역채점 문항 으로 이루어져 있었으며, 역채점 문항은 아동의 어머니가 1점 을 준 경우 7점으로, 2점을 준 경우 6점으로, 7점을 준 경우 1 점 으로 변환하여 하위영역의 점수를 산출하였다. 각 상위요인의 점수는 상위요인에 포함되는 하위영역 점수들의 평균으로 산 출하였다. 이때, 외향성 측정 시 하위영역 중 ‘수줍음’ 점수를 역 변환하여 포함하였으며, 부정적 정서 측정 시 하위영역 중 ‘반 응회복율/진정성, 점수를 역변환하여 포함하였다(Lim \& Bae, 2015; Putnam \& Rothbart, 2006). 상위요인 및 하위영역의 점수 가 높을수록 그 상위요인 및 하위영역에 해당하는 기질 특성의 수준이 높음을 의미한다.

\section{4. 자료의 통계처리}

통계분석은 IBM SPSS Statistics ver. 26을 사용하여 실시하였 다. 본 연구의 독립변수(요인)는 장애 유무 및 하위유형에 따른 집단(2개 집단: CWS, $\mathrm{CWNS} ; 3$ 개 집단: 말더듬 지속아동, 말더듬 회복아동, CWNS)과 평가 시점(Visit 3, Visit 5)이었으며, 종속변 수는 $\mathrm{CBQ}-\mathrm{SF}$ 의 상위요인(외향성, 부정적 정서, 의도적 통제) 점 수와 각 상위요인에 포함되는 하위영역의 점수였다. 본 연구는 Ambrose et al.(2015)이 Visit 1에서 세 집단 간 기질 특성 결과를 보고한 이후의 종단연구 자료(Visit 3, Visit 5)를 분석하였으므로 이미 보고된 Visit 1의 점수와는 기술통계 결과만을 비교하였다.

(1) CWS와 CWNS 두 집단 간 평가 시점에 따른 상위요인 점 수와 하위영역 점수를 비교하기 위하여 $2 \times 2$ 이요인 혼합설계분 
산분석을 각각 실시하였다. 요인 간 유의한 상호작용이 발생한 경우 추가적으로 독립표본 $t$-검정을 실시하였다.

(2) $\mathrm{CWS}$ 를 하위유형 집단으로 나누고 CWNS와 비교하기 위 하여, 즉, 세 집단 간 평가 시점에 따른 상위요인 점수와 하위영역 점수를 비교하기 위하여 $3 \times 2$ 이요인 혼합설계 분산분석을 각각 실시하였다. 요인 간 유의한 상호작용이 발생한 경우 추가적으로 일요인 분산분석 및 Tukey 사후검정을 실시하였으며, 집단의 유 의한 주효과가 발생한 경우에도 Tukey 사후검정을 실시하였다.

(3) 말더듬 하위유형인 말더듬 지속아동 집단 내에서 기질의 상위요인 및 하위영역 점수와 언어재활사가 평가한 외현적 말 더듬 중증도(일리노이 말더듬 중증도 척도) 점수의 관련성을 살 피기 위하여 Pearson 상관분석을 실시하였다. 말더듬 회복아동 집단의 경우 상관분석을 실시하지 않았다. 이 하위유형 집단은 언어재활사의 말더듬 중증도가 1 점 미만이었던 아동, 즉, 말더 듬 문제가 나타나지 않은 아동이 Visit 3에서 전체 27명 중 11명 $(40.7 \%)$ 이었으며 Visit 5에서 21명 $(77.8 \%)$ 이었기 때문이다.

\section{3. 연구결과}

3.1. $\mathrm{CWS}$ 와 $\mathrm{CWNS}$ 집단 간 평가 시점에 따른 $\mathrm{CBQ}-\mathrm{SF}$ 점수 비교 결과

$\mathrm{CWS}$ 와 $\mathrm{CWNS}$ 의 $\mathrm{CBQ}-\mathrm{SF}$ 상위요인(외향성, 부정적 정서, 의 도적 통제) 점수의 기술통계 결과는 표 2에 제시하였다. 평가 시 점을 기준으로 Visit 1의 결과(Ambrose et al., 2015)도 함께 제시 하였다. 외향성은 Visit 1과 비교하였을 때 Visit 3과 Visit 5에서 점수에 큰 변화를 보이지 않았으나 CWNS는 Visit 3보다 Visit 5 에서 평균 점수가 다소 낮아지는 모습을 보였다. 부정적 정서는 두 아동 집단 모두 Visit 1보다 Visit 3과 Visit 5에서 평균 점수가 약간 높아진 모습을 보였으며, Visit 3과 Visit 5에서는 변화가 나 타나지 않았다. 또한, CWS가 CWNS보다 상대적으로 높은 평균 점수를 보이긴 하였으나 그 차이는 근소하게 나타났다. 의도적 통제의 경우 두 아동 집단 모두 Visit 5에서 상대적으로 높은 평 균 점수를 보였다.

\subsection{1. 상위요인: 외향성}

이요인 혼합설계분산분석을 실시한 결과 요인 간 유의한 상 호작용이 나타났다 $\left[F(1,69)=4.618, p<.05\right.$, partial $\left.\eta^{2}=.063\right]$. 그림 2에 나타난 것처럼 $\mathrm{CWS}$ 의 외향성 점수는 변화가 거의 없었으 나 CWNS는 Visit 5의 점수가 Visit 3에서의 점수보다 다소 낮아 진 것을 확인할 수 있었다. 유의한 상호작용 효과가 발생하였기 때문에 독립표본 $t$-검정을 사용하여 평가 시점별로 집단 간 비교
표 2. CWS와 CWNS간 평가 시점에 따른 $\mathrm{CBQ}-\mathrm{SF}$ 상위요인(외향성, 부정적 정서, 의도적 통제) 점수의 기술통계 결과

Table 2. Descriptive statistics of CBQ-SF subscale scores (extraversion, negative affectivity, and effortful control) between CWS and CWNS across visits

\begin{tabular}{c|c|c|c|c}
\hline $\begin{array}{c}\text { Subscale } \\
\text { scores }\end{array}$ & Group & $\begin{array}{c}\text { Visit 1 } \\
\text { (Ambrose } \\
\text { et al., 2015) }\end{array}$ & Visit 3 & Visit 5 \\
\hline Extraversion & CWS & $4.69(0.55)$ & $4.75(0.54)$ & $4.79(0.54)$ \\
\cline { 2 - 5 } & CWNS & $4.88(0.64)$ & $4.97(0.56)$ & $4.81(0.65)$ \\
\hline $\begin{array}{c}\text { Negative } \\
\text { affectivity }\end{array}$ & CWS & $3.96(0.76)$ & $4.17(0.77)$ & $4.17(0.79)$ \\
\cline { 2 - 5 } $\begin{array}{c}\text { Effortful } \\
\text { control }\end{array}$ & CWS & $3.77(0.77)$ & $3.92(0.70)$ & $3.92(0.60)$ \\
\cline { 2 - 5 } & CWNS & $5.20(0.65)$ & $5.30(0.56)$ & $5.46(0.55)$ \\
\hline
\end{tabular}

Values are presented as mean (SD).

CWS, children who stutter $(\mathrm{N}=41)$; CWNS, children who do not stutter $(\mathrm{N}=30)$; Visit 1, Initial visit; Visit 3, 1 year after the initial visit; Visit 5, 2 years after the initial visit; CBQ-SF, Children's Behavior Questionnaire-Short Form Version I

를 각각 실시한 결과, Visit $3[t(69)=-1.629, p>.05]$ 과 Visit $5[t(69)=$ $-.108, p>.05]$ 모두 집단 간 외향성 점수에 유의한 차이가 없는 것으로 나타났다. 유의한 주효과는 나타나지 않았다(집단: $F(1$, $69)=.800, p>.05$; 평가 시점: $F(1,69)=1.759, p>.05)$.

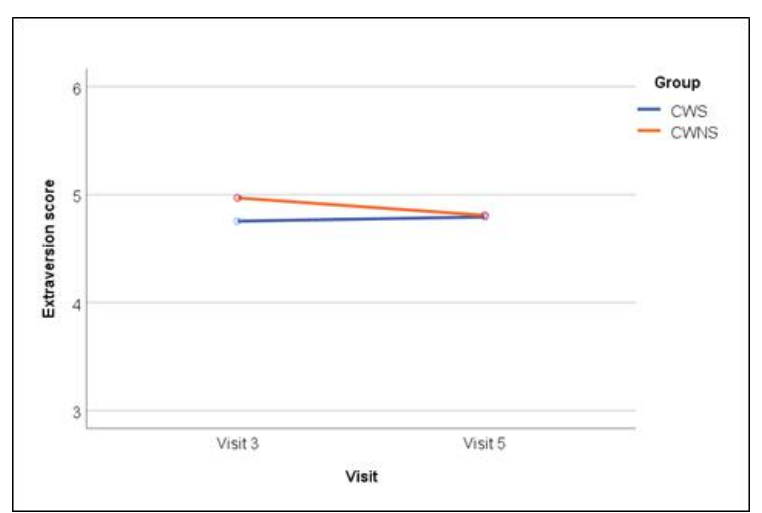

CWS, children who stutter; CWNS, children who do not stutter; Visit 3,1 year after the initial visit; Visit 5, 2 years after the initial visit.

그림 2. 집단과 평가 시점 간 상호작용 그래프: 외향성 점수 Figure 2. Interaction graphs of the Group and the Visit: Extraversion scores

외향성에 속하는 하위영역인 ‘접근성/긍정적 기대', ‘강한 자 극 선호성', ‘활동수준, ‘충동성', ‘수줍음' 각각에 대하여 이요 인 혼합설계분산분석을 실시한 결과, ‘접근성/긍정적 기대'는 요인간 유의한 상호작용이 발생하였다 $[F(1,69)=4.305, p<.05$, partial $\eta^{2}=.059$ ]. Visit 3 에서 CWNS의 평균 점수 $(M=5.24)$ 는 $\operatorname{CWS}(M=5.04)$ 보다 상대적으로 높은 모습을 보였다. 하지만 Visit 5 에서는 CWNS의 평균 점수 $(M=5.18)$ 가 감소하고 $\mathrm{CWS}$ 의 평균 점수 $(M=5.29)$ 가 상승하여 상대적으로 높은 모습을 보였 
다. 추가적으로 독립표본 $t$-검정을 사용하여 평가 시점별로 집 단 간 비교를 각각 실시한 결과, Visit 3 과 Visit 5 모두 집단 간 '접근성/긍정적 기대' 점수에 유의한 차이가 나타나지 않았다. 집단과 평가 시점 모두 유의한 주효과가 나타나지 않았다.

‘충동성'의 경우, 평가 시점의 유의한 주효과가 발생하였다 $\left[F(1,69)=4.018, p<.05\right.$, partial $\left.\eta^{2}=.055\right]$. 즉, Visit $3(M=4.30)$ 보다 Visit 5 의 평균 점수 $(M=4.14)$ 가 유의하게 감소하였다. 집단의 주효 과는 유의하지 않았으며 요인 간 상호작용 역시 유의하지 않았다.

‘강한 자극 선호성', ‘활동수준' ‘수줍음’은 통계적으로 유의 한 결과가 나타나지 않았다.

\subsection{2. 상위요인: 부정적 정서}

부정적 정서의 경우, 요인 간 상호작용이 유의하지 않았으며 $[F(1,69)=.008, p>.05]$, 각 요인의 주효과 역시 유의하지 않은 것 으로 나타났다(집단: $F(1,69)=2.187, p>.05$; 평가 시점: $F(1,69)=$ $<.001, p>.05)$.

부정적 정서에 속하는 하위영역인 ‘불안’, ‘공포', ‘분노/좌 절', ‘슬픔, '반응회복율/진정성' 각각에 대해 이요인 혼합설계 분산분석을 실시한 결과, ‘공포'는 요인 간 유의한 상호작용이 나타났다 $\left[F(1,69)=4.117, p<.05\right.$, partial $\left.\eta^{2}=.056\right]$. '공포'의 평균 점수는 $\mathrm{CWS}$ 가 $\mathrm{CWNS}$ 보다 일관되게 높게 나타났지만 $\mathrm{CWS}$ 는 Visit 3(M=4.54)에 비해 Visit 5(M=4.31)에서 평균 점수가 낮아진 반면 CWNS는 Visit 3(M=3.70)보다 Visit 5(M=3.84)에서 평균 점 수가 상승한 모습을 보였다. 추가적으로 독립표본 $t$-검정을 사 용하여 평가 시점별로 집단 간 비교를 각각 실시한 결과, Visit 3 은 CWS가 유의하게 높은 평균 점수를 보였지만 $[t(69)=3.235$, $p<.01]$ Visit 5 에서는 집단 간 유의한 차이가 발생하지 않았다. 평가 시점은 유의한 주효과가 없었으며, 집단은 유의한 주효과 가 나타났다 $\left[F(1,69)=7.437, p<.01\right.$, partial $\left.\eta^{2}=.097\right]$.

'반응회복율/진정성'은 평가 시점의 주효과가 유의하였다 $\left[F(1,69)=7.131, p<.01\right.$, partial $\left.\eta^{2}=.094\right]$. 즉, Visit 3(M=4.91)보다 Visit $5(M=4.68)$ 의 평균 점수가 유의하게 낮았다. 요인 간 상호 작용 및 집단의 주효과는 유의하지 않았다.

‘불안', ‘분노/좌절' ‘슬픔'은 통계적으로 유의한 결과가 나타 나지 않았다.

\subsection{3. 상위요인: 의도적 통제}

의도적 통제는 집단과 평가 시점 간 상호작용이 유의하지 않 았으며 $[F(1,69)=.910, p>.05]$, 집단의 유의한 주효과가 나타나지 않았다 $[F(1,69)=.029, p>.05]$. 반면 평가 시점은 유의한 주효과 가 있었다 $\left[F(1,69)=4.380, p<.05\right.$, partial $\left.\eta^{2}=.060\right]$. 즉, Visit 5의 점
수가 Visit 3의 점수보다 유의하게 높은 것으로 나타났다.

의도적 통제의 하위영역인 ‘자극의 통제', ‘주의집중력', ‘낮은 자극 선호성' ‘자극 민감성, ‘미소/웃음' 각각에 대하여 이요인 혼 합설계분산분석을 실시한 결과 모든 하위영역은 요인간 상호작용 이 유의하지 않았으며, 각 요인의 주효과 또한 유의하지 않았다.

3.2. 말더듬 하위유형에 따른 세 집단 간 평가 시점에 따른 $\mathrm{CBQ}-\mathrm{SF}$ 점수 비교 결과

$\mathrm{CWS}$ 집단을 하위유형, 즉, 말더듬 지속아동 집단과 말더듬 회복아동 집단으로 나누고 $\mathrm{CWNS}$ 집단과 $\mathrm{CBQ}-\mathrm{SF}$ 상위요인 점 수의 평균과 표준편차를 비교한 결과는 그림 3에 제시하였다.

외향성의 경우 Visit 1과 Visit 3에서는 말더듬 회복아동 집단 의 평균 점수가 상대적으로 낮았으나 Visit 5 에서 세 집단 모두 비 슷한 평균 점수를 보였다. 부정적 정서의 경우 평가 시점과 상관 없이 말더듬 지속아동 집단이 다른 아동 집단에 비해 상대적으로 높은 평균 점수를 보였다. 또한 세 집단 모두 Visit 1 의 평균 점수 가 상대적으로 낮은 모습을 보였다. 의도적 통제의 평균 점수는 평가 시점에 따른 변화를 보였는데, Visit 5의 평균 점수가 이전에 실시한 검사의 평균 점수보다상대적으로 높은 경향을 보였다.

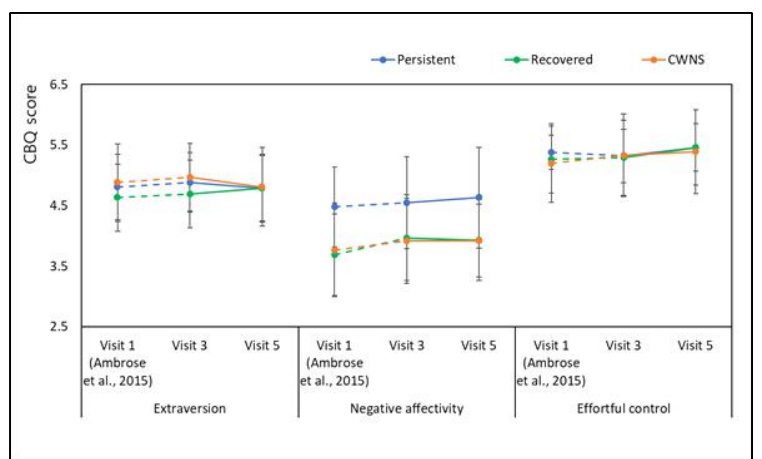

Persistent, children whose stuttering was persisted; Recovered, children whose stuttering was recovered; CWNS, children who do not stutter; Visit 1, Initial visit; Visit 3, 1 year after the initial visit; Visit 5, 2 years after the initial visit.

그림 3. 평가 시점에 따른 세 집단의 $\mathrm{CBQ}-\mathrm{SF}$ 상위요인(외향성, 부정적 정서, 의도적 통제) 기술통계 그래프

Figure 3. Descriptive statistics of CBQ-SF subscale scores(extraversion, negative affectivity, and effortful control) among three groups across visits

\subsection{1. 상위요인: 외향성}

집단과 평가 시점에 따른 이요인 혼합설계분산분석을 실시 한 결과 외향성 점수는 요인 간 상호작용이 유의한 것으로 나타 났다 $\left[F(2,68)=3.529, p<.05\right.$, partial $\left.\eta^{2}=.094\right]$. 그림 3에서 나타난 것처럼 세 집단은 Visit 3 에서의 평균 점수가 서로 다른 모습을 보였으나 Visit 5에서 평균 점수가 매우 비슷한 것으로 나타났 
다. 유의한 상호작용이 나타났으므로 추가적으로 평가 시점 별 로 일요인분산분석을 각각 실시한 결과, Visit $3[F(2,68)=1.883$, $p>.05]$ 과 Visit $5[F(2,68)=.006, p>.05]$ 모두 집단 간 차이가 없는 것으로 나타났다. 집단의 주효과는 유의하지 않았으며 $[F(2$, $68)=.534, p>.05]$, 평가 시점의 주효과 역시 유의하지 않았다 $[F(1,68)=1.029, p>.05]$.

외향성에 속하는 하위영역들, 즉, ‘접근성/긍정적 기대', ‘강 한 자극 선호성', ‘활동수준, ‘충동성’, ‘수줍음’이 집단과 평가 시점에 따른 차이가 있었는지 살펴보기 위하여 이요인 혼합설 계 분산분석을 각각 실시한 결과, 모든 하위영역들은 집단과 평 가 시점 간 유의한 상호작용이 발생하지 않았으며, 집단 및 평 가 시점의 주효과 역시 유의하지 않았다.

\subsection{2. 상위요인: 부정적 정서}

이요인 혼합설계분산분석을 실시한 결과, 부정적 정서는 요 인간 유의한 상호작용이 나타나지 않았으며 $[F(2,68)=.379$, $p>.05]$, 평가 시점에 따른 주효과도 유의하지 않았다 $[F(1,68)=$ $.076, p>.05]$ 하지만 집단의 주효과가 유의한 것으로 나타났다 $\left[F(2,68)=5.633, p<.01\right.$, partial $\left.\eta^{2}=.142\right]$. Tukey 사후검정 결과, 말 더듬 지속아동 집단이 말더듬 회복아동 집단 $(p<.05)$ 과 $\mathrm{CWNS}$ 집단 $(p<.01)$ 보다 평균 점수가 유의하게 높은 것으로 나타났다.

표 3. 유의한 주효과 혹은 상호작용 효과가 나타난 $\mathrm{CBQ}-\mathrm{SF}$ 하위영역 점수의 기술통계 결과

Table 3. Descriptive statistics of CBQ-SF component scores showing significant main effects or interaction effects

\begin{tabular}{|c|c|c|c|c|}
\hline $\begin{array}{c}\text { CBQ-SF } \\
\text { component } \\
\text { scores } \\
\end{array}$ & Group & $\begin{array}{c}\text { Visit } 1 \\
\text { (Ambrose } \\
\text { et al., 2015) }\end{array}$ & Visit 3 & Visit 5 \\
\hline \multirow{3}{*}{ Fear } & Persistent & $4.69(0.95)$ & $5.01(0.98)$ & $5.02(1.04)$ \\
\hline & Recovered & $3.69(1.02)$ & $4.30(0.99)$ & $3.95(0.93)$ \\
\hline & CWNS & $3.50(1.21)$ & $3.70(1.15)$ & $3.84(1.03)$ \\
\hline \multirow{3}{*}{$\begin{array}{c}\text { Anger/ } \\
\text { frustration }\end{array}$} & Persistent & $4.73(0.80)$ & $5.17(1.16)$ & $5.26(1.23)$ \\
\hline & Recovered & $4.41(0.95)$ & $4.22(1.04)$ & 4.19 (1.19) \\
\hline & CWNS & $4.43(1.11)$ & $4.30(1.37)$ & $3.99(1.03)$ \\
\hline \multirow{3}{*}{$\begin{array}{c}\text { Falling } \\
\text { reactivity/ } \\
\text { soothability }\end{array}$} & Persistent & $4.21(0.93)$ & $4.58(0.96)$ & $4.18(1.20)$ \\
\hline & Recovered & $5.34(0.68)$ & $5.06(1.03)$ & $4.91(1.05)$ \\
\hline & CWNS & $4.88(0.90)$ & $4.93(0.75)$ & $4.69(0.88)$ \\
\hline \multirow{3}{*}{$\begin{array}{c}\text { Inhibitory } \\
\text { control }\end{array}$} & Persistent & $4.57(0.83)$ & $4.36(0.76)$ & $4.67(0.84)$ \\
\hline & Recovered & $4.74(0.73)$ & $4.81(0.98)$ & $5.07(0.91)$ \\
\hline & CWNS & $4.72(0.84)$ & $4.91(0.95)$ & $5.01(0.98)$ \\
\hline
\end{tabular}

Values are presented as mean $(S D)$.

Persistent, children whose stuttering was persisted $(\mathrm{N}=14)$; Recovered, children whose stuttering was recovered ( $\mathrm{N}=27)$; CWNS, children who do not stutter $(\mathrm{N}=30)$; Visit 1 , Initial visit; Visit 3, 1 year after the initial visit; Visit 5, 2 years after the initial visit; CBQ-SF, Children's Behavior Questionnaire-Short Form Version I.
부정적 정서에 포함되는 하위영역, 즉, ‘불안’ ‘공포' ‘분노/ 좌절', ‘슬픔', ‘반응회복율/진정성' 각각에 대해 집단과 평가 시 점에 따른 차이가 있는지 확인하기 위하여 이요인 혼합설계분 산분석을 각각 실시한 결과, ‘공포'는 요인 간 유의한 상호작용 이 나타났다 $\left[F(2,68)=3.185, p<.05\right.$, partial $\left.\eta^{2}=.086\right]$. 표 3 에 제시 된 평균 점수를 살펴보면 전체적으로 말더듬 지속아동 집단은 평균 점수가 높았으며 평가 시점에 따른 변화가 거의 나타나지 않았다. 반면, 말더듬 회복아동 집단은 평균 점수가 Visit 3에 비 해 Visit 5 에서 감소하는 모습이 나타났으며 CWNS는 평균 점수 가 상승하는 모습을 보였다. 추가적으로 평가 시점 별 일요인분 산분석을 각각 실시한 결과, Visit 3 에서 집단 간 차이가 발생하 였다 $\left[F(2,68)=7.544, p<.01, \operatorname{partial} \eta^{2}=.182\right]$. 즉, 말더듬 지속아동 집단이 CWNS보다 ‘공포'의 평균 점수가 유의하게 높은 것으로 나타났다( $p<.01)$. Visit 5 에서도 집단 간 유의한 차이가 발생했다 $\left[F(2,68)=7.355, p<.01\right.$, partial $\left.\eta^{2}=.178\right]$. 말더듬 지속아동 집단은 말더듬 회복아동 집단 $(p<.01)$ 과 CWNS 집단 $(p<.01)$ 보다 '공포' 의 평균 점수가 유의하게 높은 것으로 나타났다. 평가 시점은 유의한 주효과가 없었으며, 집단은 유의한 주효과가 나타났다 $\left[F(2,68)=8.108, p<.01\right.$, partial $\left.\eta^{2}=.193\right]$.

‘분노/좌절'의 경우 말더듬 지속아동 집단은 평균 점수가 상 승한 모습을 보인 반면 말더듬 회복아동 집단과 $\mathrm{CWNS}$ 는 평균 점수가 낮아진 모습을 보였다(표 3). 이요인 혼합설계분산분석 결과 요인 간 유의한 상호작용이 없었으며 평가 시점의 주효과 역시 유의하지 않았다. 하지만 집단의 유의한 주효과가 나타났 다 $\left[F(2,68)=5.306, p<.01\right.$, partial $\left.\eta^{2}=.086\right]$, Tukey 사후검정 결과, 말더듬 지속아동 집단이 말더듬 회복아동 집단 $(p<.05)$ 과 $\mathrm{CWNS}$ 집단 $(p<.01)$ 보다 평균 점수가 유의하게 높은 것으로 나타났다.

‘반응회복율/진정성'의 경우, 말더듬 회복아동 집단의 평균 점수가 다른 집단보다 상대적으로 높았으며, Visit 3보다 Visit 5 의 점수가 상대적으로 낮은 모습을 보였다. 이요인 혼합설계분 산분석 결과, 요인 간 상호작용은 유의하지 않았으며, 집단에 따른 주효과도 유의하지 않았다. 하지만 평가 시점의 주효과가 유의한 모습을 보였다 $\left[F(1,68)=8.007, p<.01\right.$, partial $\left.\eta^{2}=.105\right]$. 즉, Visit 3보다 Visit 5의 평균 점수가 유의하게 낮았다(표 3).

‘불안’과 ‘슬픔’은 집단과 평가 시점 간 유의한 상호작용이 없 었으며, 평가 시점의 주효과와 집단의 주효과 또한 유의하지 않 았다.

\subsection{3. 상위요인: 의도적 통제}

이요인 혼합설계 분산분석을 실시한 결과 집단과 평가 시점 의 상호작용은 유의하지 않았으며 $[F(2,68)=.478, p>.05]$, 집단의 
주효과 역시 유의하지 않았다 $[F(2,68)=.017, p>.05]$. 하지만 평 가 시점에서 유의한 주효과가 나타났다 $[F(1,68)=4.949, p<.05$, partial $\eta^{2}=.068$ ]. 즉, Visit 5의 평균 점수가 Visit 3의 평균 점수보 다 유의하게 높은 것으로 나타났다.

의도적 통제에 속하는 하위영역들(‘자극의 통제’, ‘주의집중 력’, ‘낮은 자극 선호성', ‘자극 민감성', ‘미소/웃음’)이 집단과 평가 시점에 따른 변화가 발생하였는지 살펴보기 위하여 이요 인 혼합설계 분산분석을 각각 실시한 결과, 각 하위영역은 상호 작용이 유의하지 않았으며, 집단의 주효과 역시 유의하지 않았 다. 평가 시점의 주효과는 하위영역인 ‘자극의 통제’에서만 유 의하게 나타났다 $\left[F(1,68)=4.702, p<.05\right.$, partial $\left.\eta^{2}=.065\right]$. 표 3에 나타난 것처럼 자극의 통제 평균 점수는 Visit 3보다 Visit 5에서 유의하게 높은 것으로 나타났다.

3.3. 말더듬 지속아동 집단의 외현적 말더듬 중증도와 기질 특성과의 상관분석 결과

말더듬 지속아동 집단 $(\mathrm{N}=14)$ 을 대상으로 $\mathrm{CBQ}-\mathrm{SF}$ 상위요인 점수 및 각 상위요인에 포함되는 하위영역 점수와 아동의 외현 적 말더듬 중증도 간의 상관을 평가 시점(Visit 3 과 Visit 5)별로 각각 분석하였다.

Visit 3 에서 기질의 각 상위요인은 언어재활사의 외현적 말더 듬 중증도와 유의한 상관이 없는 것으로 나타났다. 각 상위요인 에 포함되는 하위영역도 외현적 말더듬 중증도와는 유의한 상 관이 나타나지 않았다. Visit 5 역시 기질의 각 상위요인과 상위 요인에 포함되는 하위영역은 외현적 말더듬 중증도와 유의한 상관이 없는 것으로 나타났다.

\section{4. 논의 및 결론}

본 연구는 Ambrose et al.(2015)의 후속 연구로서 종단연구를 통하여 말더듬 아동(CWS)과 말을 더듬지 않는 아동(CWNS)의 기질 특성을 비교하고자 하였다. 특히 CWS의 경우 하위유형에 따른 기질 특성을 보다 명확히 살피고 기질과 말더듬 간의 관련 성을 파악하고자 하였다. 이를 위하여 (1) 기존의 선행연구들과 동일하게 말더듬 유무에 따른 CWS와 CWNS 두 집단 간 기질의 상위요인(외향성, 부정적 정서, 의도적 통제) 및 상위요인에 포 함되는 하위영역을 평가 시점에 따라 비교하였으며, (2) CWS를 하위유형인 지속집단과 회복집단으로 나눈 후 CWNS와 평가 시점에 따른 기질 특성 비교를 실시하였다. 또한 (3) 말더듬이 지속된 아동 집단을 대상으로 기질의 상위요인 및 하위영역과 외현적 말더듬 중증도 간 상관이 있는지 평가 시점 별로 살펴보
았다.

4.1. 집단과 평가 시점에 따른 기질 특성

\subsection{1. 상위요인: 외향성}

말더듬 유무에 따라 두 집단으로 나누어 비교한 결과, 외향성 은 평가 시점에 관계 없이 집단 간에 유의한 차이가 없는 것으 로 나타났다. 상위요인 중 외향성의 경우 유의한 상호작용을 보 이기는 하였으나 각 시점별로 집단 간 차이는 나타나지 않았다. 외향성에 유의한 상호작용 효과가 나타났던 것은 외향성에 포 함되는 하위영역 중 ‘접근성/긍정적 기대' 점수에 유의한 상호 작용효과가 있었던 것과 관련지어 생각해볼 수 있을 것이다. ‘접근성/긍정적 기대'는 “즐거운 활동에 대한 흥분과 기대의 정 도(Putnam et al., 2008:389)"를 의미하는데, $\mathrm{CBQ}$ 를 사용하여 연 령에 따른 일반 아동의 기질특성을 살펴본 선행연구들은 이 하 위영역이 연령에 따른 특별한 경향성을 보이지 않음을 보고하 였다(Lee, 2004; Rothbart et al., 2001). ‘접근성/긍정적 기대'가 평 가 시점별로 집단 간 차이가 나타나지 않았던 것과 함께 고려한 다면 이 하위영역의 결과는 아동마다의 개인차로 해석할 수 있 을 것으로 보인다. 외향성의 하위영역인 ‘충동성'은 아동이 성 장하면서 유의하게 감소하는 모습을 보였지만 효과크기는 작 게 나타났다(partial $\left.\eta^{2}=.055\right)$. 평가 시점에 따른 변화는 아동의 발달적인 측면과 관련지을 수 있을 것으로 보인다. ‘충동성'은 "어떠한 자극에 반응을 시작하는 속도(Putnam et al., 2008:389)" 이며, 충동성을 조절하기 위해서는 개인 스스로의 의식적인 통 제가 필요하다(Rothbart \& Ahadi, 1994). 따라서 아동의 연령이 증가하여 인지능력 및 실행 주의력이 발달하고 정서의 자기-조 절 능력이 증가하면서 ‘충동성' 이 점차적으로 감소되는 양상을 보인 것으로 여겨진다. Cumberland-Li et al.(2004)은 정서의 자 기-조절능력을 반영하는 상위요인인 의도적 통제 점수와 ‘충동 성, 점수 간 부적 상관이 있었음을 보고하였다. 본 연구에서 Visit 5 에서의 의도적 통제 점수가 Visit 3 보다 유의하게 증가하였던 것 과 ‘충동성' 점수가 유의하게 감소하였던 것은 Cumberland-Li et al.(2004)을 지지하는 결과라고 할 수 있다.

$\mathrm{CWS}$ 를 하위유형 집단으로 나누고 세 집단 간 평가 시점에 따른 외향성 점수를 비교한 결과 역시 동일하게 나타났다. 하지 만 세 집단 간 비교 시 통계적으로 유의한 결과가 나타난 하위 영역은 존재하지 않았다. ‘접근성/긍정적 기대’와 ‘충동성' 하위 영역의 경우 두 집단 간 비교에서도 효과크기가 작았던 것을 고 려한다면 세 집단으로 구분하여 비교를 실시하면서 통계적 유 의미성을 만족하지 못한 것으로 보인다. 


\subsection{2. 상위요인: 부정적 정서}

부정적 정서는 두 집단 간 비교 시 평가 시점과 상관없이 유 의한 차이가 없는 것으로 나타났으며, 하위영역에서는 집단 간 유의한 차이가 발생한 기질 특성이 한 가지 존재하였다. 즉, 하 위영역인 ‘공포'의 정서 반응이 Visit 3에서 CWS가 유의하게 높 은 것으로 나타났다. 하지만 Visit 5 에서는 집단 간 차이가 발생 하지 않았다.

하지만 $\mathrm{CWS}$ 를 하위유형으로 집단을 나눈 뒤 비교를 실시하 자 말더듬 지속아동 집단이 평가 시점과 상관없이 다른 아동 집 단보다 부정적 정서가 유의하게 높은 것으로 나타났다. 이는 CWS가 부정적인 기질을 보였다는 선행연구(Howell et al., 2004; Ntourou et al., 2013)를 지지하는 결과이다. 또한 Visit 1에서 말 더듬 지속아동 집단의 부정적 정서가 높았다고 보고하였던 Ambrose et al.(2015)과 동일한 결과이다. 즉, 말더듬 지속아동 집단은 말더듬 시작 이후 지속기간이 짧았던 Visit 1을 포함하여 2년간 이루어진 총 세 번의 평가 시점에서 일관되게 말더듬 회 복아동 집단 및 $\mathrm{CWNS}$ 보다 높은 부정적 정서를 보이고 있음을 확인할 수 있었다.

세 집단 간 비교를 실시하자 부정적 정서를 구성하는 5 개의 하위영역 중 두 개 기질 특성, 즉, ‘공포'와 ‘분노/좌절'에서 집단 간 차이가 발생하였다. 말더듬 지속아동 집단은 ‘공포'의 평균 점수가 일관되게 높았으나 평가 시점에 따른 변화는 거의 없었 던 반면, 말더듬 회복아동 집단은 Visit 3보다 Visit 5에서 평균 점수가 상대적으로 낮아지는 모습을 보였다. 이러한 말더듬 회 복아동 집단의 점수 변화가 CWS와 CWNS 두 집단 간 비교 시 Visit 5 에서 집단 간 차이를 상쇄시켰던 것으로 보인다. Ambrose et al.(2015)은 Visit 1에서 말더듬 지속아동 집단이 말더듬 회복 아동 집단과 CWNS보다 ‘공포' 수준이 유의하게 높았다고 보고 하였으며, 본 연구 역시 말더듬 지속아동 집단의 '공포' 수준이 평가 시점과 상관없이 일관되게 높았음을 확인하였다. 말더듬 회복아동 집단은 Visit 3 에서 말더듬 지속아동 집단과 점수 차이 가 유의하지 않은 모습을 보이기도 하였으나 Visit 5에서 다시 말더듬 지속아동 집단보다 낮은 점수를 보였으며, CWNS 집단 과는 일관되게 ‘공포' 기질에 차이가 없음을 보였다.

‘분노/좌절'은 Visit 1에서 세 집단 간 유의한 차이가 발생하지 않았던 하위영역이다(Ambrose et al., 2015). 또한 본 연구에서 말더듬 유무에 따라 두 개 집단으로만 분류하였을 때는 집단 및 평가 시점에 따른 유의미한 차이가 없었다. 하지만 Visit 1 이후 1년이 지난 시점이었던 Visit 3과 2년이 지난 시점이었던 Visit 5 에서의 기질 평가 결과는 일관되게 말더듬 지속아동 집단만 평 균 점수가 Visit 1보다 상대적으로 증가한 모습을 보였으며, 다
른 아동 집단보다 유의하게 평균 점수가 높은 모습을 보였다. '분노/좌절'은 “진행 중인 과제의 중단 또는 목표의 차단과 관련 된 부정적인 정서(Putnam et al., 2008:389)"를 의미한다. 본 연구 의 결과는 말더듬이 지속된 아동들의 경우 말더듬으로 인해 지 속적 혹은 반복적으로 격게 되는 경험, 즉, 말 산출 실패, 타인과 의사소통의 어려움, 혹은 말더듬으로 인한 놀림 등 말더듬으로 인해 발생하는 부정적 경험이 기질 특성에 영향을 미쳤을 수 있 음을 시사한다. 본 연구와 동일하게 $\mathrm{CBQ}$ 를 사용하였던 Eggers et al.(2010)은 3-8세 CWS의 '분노/좌절' 점수가 CWNS보다 유 의하게 높았다고 보고하였다. 본 연구는 말더듬이 시작된 이후 지속기간이 최소 1-2년 이상 지난 시점들에서의 종단연구 결 과이고 Eggers et al.(2010)은 횡단연구를 통해 보고한 결과이지 만 연구에 참여하였던 아동의 연령이 3-8세로 넓었던 것을 고 려한다면 말더듬이 지속된 아동이 상대적으로 많이 포함되었 을 수 있으며, 말더듬 시작 이후 지속기간이 상대적으로 긴 아 동들이 포함되어 있었을 가능성이 높다. 따라서 말더듬 지속아 동 집단이 Visit 3과 Visit 5에서 보인 높은 '분노/좌절' 경향은 Eggers et al.(2010)의 결과와 맥락을 같이 한다고 할 수 있을 것 이다.

‘반응회복율/진정성’은 Visit 1에서 말더듬 지속아동 집단의 점수가 다른 집단보다 유의하게 낮았던 하위영역이다(Ambrose et al., 2015). 하지만 Visit 3과 Visit 5에서는 말더듬 유무에 따른 두 집단 비교 그리고 하위유형에 따른 세 집단 비교 모두에서 집단 간 유의한 차이가 발생하지 않았다. 다만 아동들은 Visit 3 보다 Visit 5 에서 유의하게 낮은 점수를 보였다. 하지만 Visit 1 의 평균 점수와 함께 살펴보면 세 아동 집단의 평균 점수가 특정 경향성을 보이지는 않았으며, 이는 일반아동을 대상으로 하였 던 선행연구들의 '반응회복율/진정성' 점수가 연령에 따른 특정 패턴을 보이지 않았던 것과 맥락을 같이한다(Lee, 2004; Rothbart et al., 2001). 따라서 이 하위영역은 말더듬 하위유형과는 관련 성이 약한 기질 특성으로 해석 가능할 것이다.

기질의 상위요인인 부정적 정서 점수와 부정적 정서의 하위 영역인 ‘공포', ‘분노/좌절', ‘반응회복율/진정성' 점수는 CWS를 하위유형 집단으로 분류하여 비교해야 하는 필요성 및 종단연 구의 중요성을 보여주는 결과라고 할 수 있다. 말더듬을 하위유 형으로 분류하지 않고 CWNS와 비교한 결과는 상위요인인 부 정적 정서와 하위영역인 ‘분노/좌절'의 집단 간 차이를 발견하 지 못하였고, 하위영역인 ‘공포'가 왜 평가 시점에 따른 변동성 이 발생하였는지 명확한 해석이 어려울 수 있었기 때문이다. 또 한 종단연구를 통하여 ‘반응회복율/진정성' 점수가 말더듬 하위 
유형과 관련성이 낮은 기질일 수 있음을 확인할 수 있었기 때문 이다.

\subsection{3. 상위요인: 의도적 통제}

상위요인인 의도적 통제는 두 집단 간 비교와 세 집단 간 비 교 모두에서 집단 간 차이를 보이지 않았으며, 평가 시점에 따 른 주효과만 유의한 모습을 보였다. 즉, 아동의 연령이 증가하 면서 의도적 통제 점수가 유의하게 상승하는 모습을 보였다. 전 술하였듯이 의도적 통제는 정서적 반응에 대한 자기-조절 능력 을 반영하는 상위요인이다(Rothbart \& Derryberry, 1981). 이 상 위요인은 생후 약 4세경까지 급속도로 발달하며 4세 이후 안정 화되는 경향을 보인다고 하였다(Kochanska \& Knaack, 2003). 따 라서 본 연구에 참여한 아동들 역시 연령이 증가하며 의도적 통 제 점수가 상승한 것으로 해석할 수 있을 것이다. 다만, 본 연구 결과는 4세 이후에도 의도적 통제가 지속적으로 발달할 수 있 음을 시사하며, 하위영역 중 ‘자극의 통제’, 즉, “부적절한 행동 이나 반응을 억제하는 능력(Putnam et al., 2008:389)"이 Visit 3보 다 Visit 5에서 유의하게 상승하였던 것이 의도적 통제 결과에 부분적으로 영향을 미쳤을 것으로 보인다. 또한 Ambrose et al.(2015)이 Visit 1에서 집단 간 의도적 통제 점수에 유의한 차이 가 없었다고 보고했던 결과를 종합하여볼 때 의도적 통제 및 의 도적 통제에 포함되는 하위영역은 말더듬 유무 및 말더듬 하위 유형과는 관련성이 낮다고 해석할 수 있을 것이다.

4.2. 외현적 말더듬 중증도와 기질과의 상관

말더듬 지속아동 집단의 외현적 말더듬 중증도와 기질 간 상 관분석 결과 말더듬 중증도 점수와 기질의 상위요인 및 하위영 역 점수는 관련이 없는 것으로 나타났다. 이는 학령전 $\mathrm{CWS}$ 의 기질과 말더듬 중증도 간 유의한 상관이 없었음을 보고하였던 선행연구(Eggers et al., 2010; Lee et al., 2020)를 지지하는 결과이 다. 또한, 말더듬 지속아동 집단이 다른 아동 집단보다 유의하 게 높은 점수를 보였던 상위요인인 부정적 정서와 부정적 정서 의 하위영역인 ‘공포', ‘분노/좌절’이 외현적 중증도와 상관이 없었던 결과는 외현적인 말더듬 중증도와 기질 특성을 단순하 게 관련짓거나 상호 예측하기는 어렵다는 것을 시사한다. 따라 서 외현적인 말더듬 특성만이 아니라 말더듬과 관련된 아동의 내면적 특성 혹은 말더듬과 관련된 아동의 경험이 기질과 관련 성이 있는지 살펴보는 연구가 추가적으로 필요할 것으로 보인다.

4.3. 결론: 말더듬과 기질의 관계

본 종단연구는 말더듬의 지속과 회복이라는 이질적인 경로
를 보이는 말더듬 하위유형 집단 간 기질 특성을 비교하여 기질 과 말더듬의 관련성을 살펴보고, 반복적인 혹은 지속적인 말더듬 관련 경험이 아동의 기질에 영향을 미칠 수 있는지 알아보았다.

본 연구 결과를 통해 말더듬 하위유형 간 기질 특성에 차이가 있음을 확인하였다. 즉, 말더듬이 지속된 아동은 기질의 상위요 인인 부정적 정서가 높고, 부정적 정서의 하위영역인 '공포' 수 준이 높은 모습을 보였다. 또한 종단연구의 첫 평가(Visit 1) 이 후 1 년이 지난 시점과 2 년이 지난 시점에서 부정적 정서의 하위 영역인 ‘분노/좌절' 수준이 높은 모습을 보여 말더듬과 관련된 경험이 아동의 기질에 부분적으로 영향을 미칠 수 있음을 예측 할 수 있었다. 말더듬 회복아동 집단은 기질 평가가 이루어진 2 년간 CWNS와 어떠한 기질에서도 차이를 보이지 않았다. 하지 만 이 아동들 역시 첫 평가에서 말더듬으로 진단받았었으며, 말 더듬이 지속된 아동들의 말더듬 중증도와 유의한 차이를 보이 지 않았었다. 이를 통해 기질 특성은 말더듬의 이질적 경로, 즉, 지속 및 회복과 관련이 있는 요인 중 하나가 될 수 있음을 확인 할 수 있었으며, 이는 의사소통-정서모델(Conture et al., 2006)과 역동적 다중요인 경로 이론(Smith \& Weber, 2017)을 지지하는 결과라고 할 수 있다.

\section{4. 후속 연구를 위한 제언}

본 연구는 말더듬 시작 이후 지속기간이 12 개월 이내인 CWS 를 대상으로 말더듬 하위유형에 따라 집단을 나누고 2년간 기 질 특성 및 기질의 변화를 살폈다. 후속연구에서 2 년 이후의 기 간을 포함한 장기적인 종단연구가 이루어져서 말더듬 하위유 형에 따른 기질 특성 및 기질의 변화를 살핀다면 말더듬과 기질 의 관련성을 보다 세밀하게 확인할 수 있을 것이다.

또한 본 연구는 주 양육자 중 어머니의 보고를 기준으로 아동 의 전반적인 기질 특성을 측정 및 비교하였다. 본 연구에서 확 인된 말더듬 하위유형 집단 간 기질 차이, 즉, 부정적 정서 및 관 련 하위영역을 연구자가 직접 평가할 수 있는 실험설계를 통하 여 살펴본다면 말더듬 아동의 기질 특성을 보다 구체적으로 파 악할 수 있을 것이다.

\section{References}

Ahadi, S. A., Rothbart, M. K., \& Ye, R. (1993). Child temperament in the US and China: Similarities and differences. European Journal of Personality, 7(5), 359-378.

Ambrose, N. G., Yairi, E., Loucks, T. M., Seery, C. H., \& Throneburg,

R. (2015). Relation of motor, linguistic and temperament factors in 
epidemiologic subtypes of persistent and recovered stuttering: Initial findings. Journal of Fluency Disorders, 45, 12-26.

Anderson, J. D., Pellowski, M. W., Conture, E. G., \& Kelly, E. M. (2003). Temperamental characteristics of young children who stutter. Journal of Speech, Language, and Hearing Research, 46(5), 1221-1233.

Arnold, H. S., Conture, E. G., Key, A. P. F., \& Walden, T. (2011). Emotional reactivity, regulation and childhood stuttering: A behavioral and electrophysiological study. Journal of Communication Disorders, 44(3), 276-293.

Bates, J. E., Freeland, C. A. B., \& Lounsbury, M. L. (1979). Measurement of infant difficultness. Child Development, 50(5), 794-803.

Buss, A. H., \& Plomin, R. (1984). Temperament: Early developing personality traits. Hillsdale, NJ: Lawrence Erlbaum Associates.

Cha, H. (2015). Characteristics of temperament and communication attitudes in school-age children who stutter (Master's thesis). Chosun University, Gwangju, Korea.

Chang, S. E., Zhu, D. C., Choo, A. L., \& Angstadt, M. (2015). White matter neuroanatomical differences in young children who stutter. Brain, 138(3), 694-711.

Choi, D., Conture, E. G., Walden, T. A., Jones, R. M., \& Kim, H. (2016). Emotional diathesis, emotional stress, and childhood stuttering. Journal of Speech, Language, and Hearing Research, 59(4), 616-630.

Conture, E. G., Walden, T. A., Arnold, H. S., Graham, C. G., Hartfield, K. N., \& Karrass, J. (2006). Communication-emotional model of stuttering. In N. Bernstein Ratner \& J. A. Tetnowski (Eds.), Current issues in stuttering research and practice (pp. 17-46). Mahwah, NJ: Lawrence Erlbaum Associates.

Cumberland-Li, A., Eisenberg, N., \& Reiser, M. (2004). Relations of young children's agreeableness and resiliency to effortful control and impulsivity. Social Development, 13(2), 193-212.

de la Osa, N., Granero, R., Penelo, E., Domènech, J. M., \& Ezpeleta, L. (2014). The short and very short forms of the Children's Behavior Questionnaire in a community sample of preschoolers. Assessment, 21(4), 463-476

Eggers, K., De Nil, L. F., \& Van den Bergh, B. R. H. (2009). Factorial temperament structure in stuttering, voice-disordered, and typically developing children. Journal of Speech, Language, and
Hearing Research, 52(6), 1610-1622.

Eggers, K., De Nil, L. F., \& Van den Bergh, B. R. H. (2010). Temperament dimensions in stuttering and typically developing children. Journal of Fluency Disorders, 35, 355-372.

Eggers, K., De Nil, L. F., \& Van den Bergh, B. R. H. (2013). Inhibitory control in childhood stuttering. Journal of Fluency Disorders, 38(1), 1-13.

Embrechts, M., Ebben, H., Franke, P., \& van de Poel, C. (2000, August). Temperament: A comparison between children who stutter and children who do not stutter. In H. G. Bosshardt, J. S. Yaruss, \& H. F. M. Peters (Eds.), Proceedings of the 3rd World Congress on fluency disorders: Theory, research, treatment, and self-help (pp. 557-562). Nijmegen, Netherlands.

Felsenfeld, S., van Beijsterveldt, C. E. M., \& Boomsma, D. I. (2010). Attentional regulation in young twins with probable stuttering, high nonfluency, and typical fluency. Journal of Speech, Language, and Hearing Research, 53(5), 1147-1166.

Howell, P., Davis, S., Patel, H., Cuniffe, P., Downing-Wilson, D., Au-Yeung, J., \& Williams, R. (2004, August). Fluency development and temperament in fluent children and children who stutter. In A. Packman, A. Meltzer, \& H. F. M. Peters (Eds.), Proceedings of the 4th World Congress on fluency disorders: Theory, research, and therapy in fluency disorders (pp. 250-256). Nijmegen, Netherlands. Jones, R. M., Walden, T. A., Conture, E. G., Erdemir, A., Lambert, W. E., \& Porges, S. W. (2017). Executive functions impact the relation between respiratory sinus arrhythmia and frequency of stuttering in young children who do and do not stutter. Journal of Speech, Language, and Hearing Research, 60(8), 2133-2150.

Kang, C., Riazuddin, S., Mundorff, J., Krasnewich, D., Friedman, P., Mullikin, J., \& Drayna, D. (2010). Mutations in the lysosomal enzyme-targeting pathway and persistent stuttering. The New England Journal of Medicine, 362, 677-685.

Kefalianos, E., Onslow, M., Packman, A., Vogel, A., Pezic, A., Mensah, F., Conway, L., ... Reilly, S. (2017). The history of stuttering by 7 years of age: Follow-up of a prospective community cohort. Journal of Speech, Language, and Hearing Research, 60(10), 2828-2839.

Kochanska, G., \& Knaack, A. (2003). Effortful control as a personality characteristic of young children: Antecedents, correlates, and consequences. Journal of Personality, 71(6), 1087-1112. 
Kusanagi, E. (1993). A psychometric examination of the Children's Behavior Questionnaire. Research and Clinical Center for Child Development: Annual Report, 15, 25-33.

Lee, E. A., Choi, S. H., Choi, C. H., \& Lee, K. (2020). Temperamental characteristics of pre-school children who stutter. Audiology and Speech Research, 16(4), 339-346.

Lee, K. O. (2004). Validation study for CBQ scale with Korean children. Journal of Early Childhood Education, 24(5), 101-120.

Lewis, K. E., \& Golberg, L. L. (1997). Measurements of temperament in the identification of children who stutter. European Journal of Disorders of Communication, 32(4), 441-448.

Lim, J. Y., \& Bae, Y. J. (2015). Validation study of Korean version of the Rothbart's Children's Behavior Questionnaire. Korean Journal of Human Ecology, 24(4), 477-497.

Ntourou, K., Conture, E. G., \& Walden, T. A. (2013). Emotional reactivity and regulation in preschool-age children who stutter. Journal of Fluency Disorders, 38(3), 260-274.

Putnam, S. P., \& Rothbart, M. K. (2006). Development of short and very short forms of the Children's Behavior Questionnaire. Journal of Personality Assessment, 87(1), 103-113.

Putnam, S. P., Rothbart, M. K., \& Gartstein, M. A. (2008). Homotypic and heterotypic continuity of fine-grained temperament during infancy, toddlerhood, and early childhood. Infant and Child Development, 17(4), 387-405.

Reilly, S., Onslow, M., Packman, A., Cini, E., Conway, L., Ukoumunne, O., Bavin, E. L., ... Wake, M. (2013). Natural history of stuttering to 4 years of age: A prospective community-based study. Pediatrics, 132(3), 460-467.

Reilly, S., Onslow, M., Packman, A., Wake, M., Bavin, E. L., Prior, M., Eadie, P., ... Ukoumunne, O. C. (2009). Predicting stuttering onset by the age of 3 years: A prospective, community cohort study. Pediatrics, 123(1), 270-277.

Riley, G., \& Riley, J. G. (2000). A revised component model for diagnosing and treating children who stutter. Contemporary Issues in Communication Science and Disorders, 27(Fall), 188-199.

Rothbart, M. K., \& Ahadi, S. A. (1994). Temperament and the development of personality. Journal of Abnormal Psychology, 103(1), 55-66.

Rothbart, M. K., Ahadi, S. A., Hershey, K. L., \& Fisher, P. (2001). Investigations of temperament at three to seven years: The
Children's Behavior Questionnaire. Child Development, 72(5), 1394-1408.

Rothbart, M. K., \& Derryberry, D. (1981). Development of individual differences in temperament. In M. E. Lamb \& A. L. Brown (Eds.), Advances in developmental psychology (Vol. 1, pp. 37-86). Hillsdale, NJ: Lawrence Erlbaum Associates.

Sleddens, E. F. C., Kremers, S. P. J., Candel, M. J. J. M., De Vries, N. N. K., \& Thijs, C. (2011). Validating the children's behavior questionnaire in Dutch children: Psychometric properties and a cross-cultural comparison of factor structures. Psychological Assessment, 23(2), 417-426.

Smith, A., \& Weber, C. (2017). How stuttering develops: The multifactorial dynamic pathways theory. Journal of Speech, Language, and Hearing Research, 60(9), 2483-2505.

van der Merwe, B., Robb, M. P., Lewis, J. G., \& Ormond, T. (2011). Anxiety measures and salivary cortisol responses in preschool children who stutter. Contemporary Issues in Communication Science and Disorders, 38(Spring), 1-10.

Walsh, B., Mettel, K. M., \& Smith, A. (2015). Speech motor planning and execution deficits in early childhood stuttering. Journal of Neurodevelopmental Disorders, 7(1), 1-12.

Watkins, R. (2005). Language abilities of young children who stutter. In E. Yairi \& N. G. Ambrose (Eds.), Early childhood stuttering: For clinicians by clinicians (pp. 235-251). Austin, TX: PRO-ED.

Yairi, E., \& Ambrose, N. G. (2005). Early childhood stuttering: For clinicians by clinicians. Austin, TX: PRO-ED.

\footnotetext{
- 전희정(HeeCheong Chon) 교신저자 조선대학교 언어치료학과 부교수 광주광역시 동구 필문대로 309 Tel: 062-230-7857 Email: hchon@chosun.ac.kr 관심 분야: 발달성말더듬, 말운동통제, 비유창성, 말더듬 관 련요인
} 


\title{
말더듬이 지속된 아동과 회복된 아동의 기질 특성 비교: 종단연구*
}

\author{
전 희 정 \\ 조선대학교 언어치료학과
}

\begin{abstract}
국문초록
본 연구의 목적은 말더듬의 지속과 회복에 따른 하위유형의 기질 특성을 종단적으로 비교하고, 외현적 말더듬 중 증도와 기질 특성의 관련성을 살피는 것이었다. 연구 참여자는 학령전 아동으로 41 명의 말더듬 아동(CWS, children who stutter)과 30 명의 말을 더듬지 않는 아동(CWNS, children who do not stutter)이었다. 아동들은 4년간 종단연구에 참여하였으며, 마지막 평가에 참여하였을 때 전체 CWS 중 27명은 말더듬이 회복된 아동으로, 14 명은 말더듬이 지 속된 아동으로 최종 진단되었다. 각 아동의 기질 특성은 유아기질척도-간편형을 사용하여 평가하였으며, 기질 평 가는 첫 평가 이후 1 년이 지난 시점과 첫 평가 이후 2 년이 지난 시점에서 각각 이루어졌다. 기질 특성 비교를 위해 유아기질척도-간편형의 상위요인(외향성, 부정적 정서, 의도적 통제)과 15 개의 하위영역 점수를 분석하였으며, 집 단과 평가 시점에 따른 차이를 각각 비교하였다. 연구 결과, 말더듬이 지속된 아동 집단은 말더듬이 회복된 아동 집 단과 CWNS보다 상위요인인 부정적 정서 점수가 평가 시점과 관계없이 유의하게 높은 것으로 나타났다. 또한, 말 더듬이 지속된 아동 집단은 다른 아동 집단보다 부정적 정서를 구성하는 하위영역인 ‘공포'와 ‘분노/좌절’ 점수가 유의하게 높았다. 말더듬이 지속된 아동 집단을 대상으로 평가 시점별로 외현적 말더듬 중증도와 기질의 상위요인 및 하위영역 점수 간 상관분석을 실시한 결과, 외현적 말더듬 중증도와 기질 특성은 유의한 상관을 보이지 않았다. 본 연구결과는 기질 특성이 말더듬의 지속 및 회복과 관련 있는 요인이라는 이론적 관점을 지지하며, 시간이 지남 에 따라 기질이 말더듬으로 인한 반복적인 경험의 영향을 받을 수 있음을 시사한다.
\end{abstract}

핵심어: 아동기 말더듬, 종단연구, 지속, 회복, 하위유형, 기질

\section{참고문헌}

이경옥 (2004). 유아기질 척도(CBQ)의 타당화를 위한 기초 연구.

유아교육연구, 24(5), 101-120.

이은애, 최성희, 최철희, 이경재. (2020). 학령전 말더듬 아동의 기

질특성. 청능재활, 16(4), 339-346.

임지영, 배윤진(2015). 한국판 Rothbart 유아용 기질 척도(Children's

Behavior Questionnaire)의 타당화. 한국생활과학회지, 24(4),

477-497.

차현 (2015). 학령기 말더듬 아동과 일반 아동의 기질과 의사소통

태도 특성. 조선대학교 석사학위논문.

\footnotetext{
* 본 연구는 University of Illinois at Urbana-Champaign의 Illinois International Stuttering Research Program에서 실시되었음. 본 연구는 National Institutes of Health, National Institute on Deafness and Other Communication Disorders의 연구비(\# R01-DC05210, First PI: Ehud Yairi; second PI: Nicoline G. Ambrose) 지원을 받았음.
} 